\title{
Perlindungan Hukum Terhadap Desa di Indonesia
}

\section{Legal Protection Against Villages in Indonesia}

\author{
Danang Ari Wibowo \\ Universitas Nahdlatul Ulama Surakarta \\ indonews01@yahoo.com
}

\begin{abstract}
Abstrak
Desa merupakan struktur organisasi terkecil dalam sistem pemerintahan di Indonesia. Desa mempunyai hak asal usul dan hak tradisional yang digunakan dalam mengatur dan mengurus kepentingan masyarakat setempat, serta ikut berperan dalam mewujudkan cita-cita kemerdekaan bangsa Indonesia berdasarkan Undang-Undang Dasar Negara Republik Indonesia Tahun 1945. Dalam perkembangan ketatanegaraan Republik Indonesia, desa telah maju dan berkembang dalam berbagai bentuk, sehingga sangat perlu untuk dilindungi dan diberdayakan agar menjadi desa yang kuat, maju, mandiri dan demokratis, sehingga dapat menciptakan landasan yang kuat dalam melaksanakan pemerintahan dan pembangunan menuju masyarakat yang adil, makmur dan sejahtera. Penelitian ini menggunakan metode penelitian Library Research atau penelitian kepustakaan. Berdasarkan penelitian kepustakaan didapatkan kesimpulan sebagai berikut : Desa adalah kesatuan masyarakat hukum yang memiliki batas wilayah yang berwenang untuk mengatur dan mengurus urusan pemerintahan, kepentingan masyarakat setempat berdasarkan prakarsa masyarakat, hak asal usul, dan/atau hak tradisional yang diakui dan dihormati dalam sistem pemerintahan Negara Kesatuan Republik Indonesia. Di Indonesia perlindungan hukum terhadap desa adalah dengan adanya Undang-Undang Republik Indonesia Nomor 6 Tahun 2014 Tentang Desa.
\end{abstract}

\section{Kata Kunci: Perlindungan Hukum, Desa, Indonesia}

\section{Abstract}

The village is the smallest organizational structure in the government system in Indonesia. Villages have the right of origin and traditional rights used in organizing and managing the interests of local communities, and play a role in realizing the ideals of Indonesian independence under the Constitution of the State of the Republic of Indonesia Year 1945. In the development of the Republic of Indonesia, the village has advanced and develop in various forms, so it is necessary to be protected and empowered to become a strong, advanced, independent and democratic village, so as to create a strong foundation in implementing governance and development towards a just, prosperous and prosperous society. This research uses research method of Library Research or library research. Based on the literature research, the following conclusions are found: The village is a legal community unity that has the boundaries of the territory authorized to regulate and administer government affairs, the interests of local communities based on community initiatives, rights of origin, and / or traditional rights recognized and respected in the system of state government Unity of the Republic of Indonesia. In Indonesia the legal protection of the village is by the Law of the Republic of Indonesia Number 6 Year 2014 About the Village.

Keywords: Legal Protection, Village, Indonesia 


\section{A. Pendahuluan}

Pemerintahan di Negara Kesatuan Republik Indonesia berdasarkan urutan yang tertinggi sampai yang terendah yaitu diawali dengan Pemerintahan Pusat atau biasa disebut Pemerintahan Republik Indonesia, dibawahnya lagi terdapat Pemerintahan Provinsi, selanjutnya dibawahnya lagi terdapat Pemerintahan Kabupaten atau Kota, selanjutnya Pemerintahan Kecamatan dan yang terakhir atau terendah adalah Pemerintahan Desa.

Desa atau yang disebut dengan nama lain telah ada sebelum Negara Kesatuan Republik Indonesia terbentuk. Sebagai bukti keberadaannya, Penjelasan Pasal 18 Undang-Undang Dasar Negara Republik Indonesia Tahun 1945 (sebelum perubahan) menyebutkan bahwa "Dalam territori Negara Indonesia "Zelfbesturende landschappen" dan Volksgemeenschappen"“,seperti desa di Jawa dan Bali, Nagari di Minangkabau, dusun dan marga di Palembang, dan sebagainya. Daerah-daerah itu mempunyai susunan Asli dan oleh karenanya dapat dianggap sebagai daerah yang bersifat istimewa. Negara Republik Indonesia menghormati kedudukan daerah-daerah istimewa tersebut dan segala peraturan negara yang mengenai daerah-daerah itu akan mengingati hak-hak asal usul daerah tersebut". Oleh sebab tetap diakui dan diberikan jaminan keberlangsungan hidupnya dalam Negara Kesatuan Republik Indonesia.

Keberagaman karakteristik dan jenis Desa, atau yang disebut dengan nama lain, tidak menjadi penghalang bagi para pendiri bangsa (founding fathers) ini untuk menjatuhkan pilihannya pada bentuk negara kesatuan. Meskipun disadari bahwa dalam suatu negara kesatuan perlu terdapat homogenitas, tetapi Negara Kesatuan Republik Indonesia tetap memberikan pengakuan dan jaminan terhadap keberadaan kesatuan masyarakat hukum dan kesatuan masyarakat hukum adat beserta hak tradisionalnya.

Desa merupakan bagian dari struktur organisasi terkecil dalam sistem pemerintahan di Indonesia. Desa mempunyai hak asal usul dan hak tradisional yang digunakan dalam mengatur dan mengurus kepentingan masyarakat setempat, serta ikut berperan dalam mewujudkan cita-cita kemerdekaan bangsa Indonesia berdasarkan UndangUndang Dasar Negara Republik Indonesia Tahun 1945. Dalam perkembangan ketatanegaraan Republik Indonesia, desa telah maju dan berkembang dalam berbagai bentuk, sehingga sangat perlu dan layak untuk dilindungi dan diberdayakan agar menjadi desa yang kuat, maju, mandiri dan demokratis, sehingga dapat menciptakan landasan yang kuat dalam melaksanakan pemerintahan dan pembangunan menuju masyarakat yang adil, makmur dan sejahtera.

Desa dalam susunan dan tata cara penyelenggaraan pemerintahan dan pembangunan perlu diatur tersendiri dengan undang-undang, dalam sejarahnya Negara Indonesia telah melindungi keberdaan desa dengan adanya UndangUndang yang mengatur tentang desa sejak era awal kemerdekaan yaitu pada tahun 1948 dan terus diperbaharui sesuai dengan 
perkembangan zaman saat ini. Tercatat sudah sebanyak sembilan kali UndangUndang tentang desa tersebut telah mengalami penyempurnaan yang lebih baik lagi agar sesuai dengan kemajuan masyarakat desa saat ini.

Berdasarkan uraian dalam pendahuluan tersebut diatas, maka selanjutnya akan dapat dikemukakan rumusan masalah adalah "Bagaimanakah Perlindungan Hukum Terhadap Pemerintahan Desa Di Indonesia?". Tujuan utama dari adanya penelitian ini adalah mengetahui Perlindungan Hukum Terhadap Pemerintahan Desa Di Indonesia.

\section{B. Metode Penelitian}

Metode penelitian pada dasarnya merupakan cara ilmiah untuk mendapatkan data dengan tujuan dan kegunaan tertentu. Berdasarkan hal tersebut terdapat empat kata kunci yang perlu diperhatikan yaitu cara ilmiah, data, tujuan dan kegunaan. ${ }^{1}$

Penelitian ini menggunakan metode penelitian Library Research atau penelitian kepustakaan. Penelitian kepustakaan memanfaatkan sumber perpustakaan untuk memperoleh data penelitiannya, sumber data penelitian didapatkan dari artikel-artikel di bukubuku, paper, jurnal cetak atau online, media cetak atau elektronik, data-data dari internet atau website dan lain sebagainya. Sehingga dapat disimpulkan bahwa riset pustaka membatasi kegiatannya hanya pada bahan-bahan koleksi perpustakaan saja tanpa harus memerlukan riset lapangan.

\footnotetext{
${ }^{1}$ Sugiyono, Metode Penelitian Kuantitatif kualitatif Dan R\&D, Bandung : Penerbit Alfabeta,2009, hal 2
}

Penelitian kepustakaan memiliki empat ciri utama yaitu Peneliti berhadapan langsung dengan teks atau data angka dan bukan dengan pengetahuan langsung dari lapangan atau saksi mata berupa kejadian orang atau benda lainnya, Data pustaka bersifat siap pakai artinyan peneliti tidak pergi kemanamana kecuali hanya berhadapan langsung dengan bahan sumber yang sudah tersedia di perpustakaan, Data pustaka umumnya adalah sumber sekunder dalam arti bahwa peneliti memperoleh bahan dari tangan kedua dan bukan data orisinil dari tangan pertama dilapangan, kondisi data pustaka tidak dibatasi oleh ruang dan waktu sehingga Peneliti berhadapan dengan informasi statik atau tetap. ${ }^{2}$

\section{Pembahasan}

1. Pengertian Desa Menurut Para Ahli Dan Menurut Undang-Undang Di Indonesia

Menurut Bambang Utoyo, Desa adalah tempat sebagian besar penduduk yang bermata pencarian dibidang pertanian dan menghasilkan bahan makanan. Sementara itu , menurut Sutarjo kartohadikusumo, Desa adalah kesatuan hukum tempat tinggal suatu masyarakat yang berhak menyelenggarakan rumah tangganya sendiri merupakan pemerintahan terendah dibawah camat.

Menurut R.Bintarto, Desa adalah perwujudan geografis yang ditimbulkan oleh unsur-unsur fisiografis, sosial, ekonomi, politik kultural setempat dalam hubungan dan pengaruh timbal balik dengan daerah lain. Menurut S.D Misra,

\footnotetext{
2 Ryan Febrianti, Memahami Metode Penelitian Kepustakaan, febrianti.blogspot.co.id/2015/03/memahamimetode-penelitian-kepustakaan.html?m=1,diakses, tanggal 19 April 2018
} 
Desa adalah suatu kumpulan tempat tinggal dan kumpulan daerah pertanian dengan batas-batas tertentu yang luasnya antara 50 - 1000 are. Menurut William Ogburn dan MF Nimkoff, Desa adalah kesatuan organisasi kehidupan sosial didalam daerah terbatas. ${ }^{3}$

Pengertian Desa Menurut Undang-Undang antara lain:

a. Menurut Undang-Undang Nomor 5 Tahun 1979, Desa adalah suatu wilayah yang ditempati oleh sejumlah penduduk sebagai kesatuan masyarakat termasuk di dalamnya kesatuan masyarakat hukum yang mempunyai organisasi pemerintahan terendah langsung dibawah camat dan berhak menyelenggarakan rumah tangganya sendiri dalam ikatan Negara Kesatuan Republik Indonesia.

b. Menurut Undang-Undang Nomor 22 Tahun 1999, Desa adalah kesatuan masyarakat hukum yang memiliki kewenangan untuk mengatur dan mengurus kepentingan masyarakat setempat berdasarkan asal usul dan adat istiadat setempat yang diakui dalam sistem pemerintahan nasional dan berada di daerah kabupaten.

c. Menurut Undang-Undang Nomor 6 Tahun 2014, Desa adalah desa dan desa adat atau yang disebut dengan nama lain, selanjutnya disebut Desa, adalah kesatuan masyarakat

\footnotetext{
3 Anonim, 20 Pengertian Desa Menurut Para Ahli Terlengkap,http://www.pelajaran.co.id/2017/17/20pengertian-desa-menurut-para-ahli-terlengkap.html , diakses tanggal 19 April 2018
}

hukum yang memiliki batas wilayah yang berwenang untuk mengatur dan mengurus urusan pemerintahan, kepentingan masyarakat setempat berdasarkan prakarsa masyarakat, hak asal usul, dan/atau hak tradisional yang diakui dan dihormati dalam sistem pemerintahan Negara Kesatuan Republik Indonesia.

\section{Perlindungan Hukum Terhadap Pemerintahan Desa Di Indonesia}

\section{a. Teori Negara Hukum}

Untuk menganalisis tentang Perlindungan Hukum Terhadap Pemerintahan Desa Di Indonesia menggunakan teori negara hukum. Indonesia adalah negara hukum berikut ini beberapa pendapat para ahli tentang pengertian negara hukum. Menurut Prof.R.Djokosutomo,SH menyatakan bahwa dalam UUD 1945 yang kita pelajari selama ini dijelaskan bahwa negara hukum merupakan kedaulatan hukum yang berlaku. Negara sendiri sebagai subyek hukum juga dapat dituntut ke pengadilan karena dianggap telah melanggar hukum.

Prof.Dr.Ismail Suny,SH,M.CL dalam brosur beliau "Mekanisme Demokrasi Pancasila" mengatakan bahwa negara hukum Indonesia memuat unsur-unsur: menjunjung tinggi hukum, adanya pembagian kekuasaan, adanya perlindungan terhadap hak-hak asasi manusia serta remedi-remedi prosedural untuk memepertahankannya, dimungkinkan adanya peradilan administrasi. $^{4}$

\footnotetext{
${ }^{4}$ Anonim, Pengertian Negara Hukum Menurut Para ahli, https://tesishukum.com/pengertian-negarahukum-menurut-para-ahli/, diakses tanggal 19 April 2018
} 
Teori negara hukum sangat menjunjung tinggi sistem hukum yang menjamin kepastian hukum dan perlindungan terhadap hak asasi manusia. Kepastian hukum secara nyata direalisasikan dengan adanya kaidah-kaidah hukum yang ditegakkan dan dilaksanakan. Pendapat Soerjono Soekanto (1983), kepastian hukum mengharuskan diciptakannya peraturan umum atau kaidah hukum yang berlaku umum. Agar terciptanya suasana yang aman dan tenteram dalam masyarakat, maka kaidah-kaidah yang termaksud harus ditegakkan serta dilaksanakan dengan tegas. ${ }^{5}$

Menjalankan negara hukum janganlah dianggap sebagai rutinitas menjalankan undang-undang belaka. Ia adalah kerja besar yang selain menguras energi, juga membutuhkan komitmen, dedikasi, empati, serta perilaku inovatif dan kreatif. Mungkin cara visioner boleh ditambahkan disini. Jika diperlukan demi kebahagiaan bangsa kita, dibikinlah teori sendiri, diciptakan asas dan doktrin yang sesuai dengan kebutuhan bangsa sendiri. Itu berarti, diatas segalanya kita perlu menegaskan suatu cara pandang, bahwa negara hukum itu adalah untuk kesejahteraan dan kebahagiaan bangsa Indonesia. $^{6}$

Berdasarkan teori negara hukum yang telah dibahas diatas dapat disimpulkan bahwa Perlindungan Hukum Terhadap Pemerintahan Desa adalah dengan adanya Peraturan Perundang-undangan yang

\footnotetext{
${ }^{5}$ Soerjono Soekanto, Penegakan Hukum, Jakarta: Penerbit Bina Cipta, 1983, hal 42

${ }^{6}$ Satjipto Raharjo, Membedah Hukum Progresif, Jakarta: Penerbit Buku Kompas, 2008, hal 53
}

mengatur tentang Desa. Peraturan Perundang-undangan tersebut telah mengalami beberapa kali perubahan yaitu :Undang-undang Nomor 22 Tahun 1948 tentang Pokok Pemerintahan Daerah, Undang-undang Nomor 1 Tahun 1957 tentang Pokok-pokok Pemerintahan Daerah, Undang-undang Nomor 18 Tahun 1965 tentang Pokok-pokok Pemerintahan Daerah, Undang-undang Nomor 19 Tahun 1965 tentang Desa Praja Sebagai Bentuk Peralihan Untuk Mempercepat Terbentukanya Daerah Tingkat III di Seluruh Wilayah RI, Undang-undang Nomor 5 Tahun 1974 tentang Pokokpokok Pemerintahan di Daerah, Undangundang Nomor 5 Tahun 1975 tentang Pemerintahan Desa, Undang-undang Nomor 22 Tahun 1999 tentang Pemerintahan Daerah, Undang-undang Nomor 32 Tahun 2004 tentang Pemerintahan Daerah dan yang terbaru Undang-undang Nomor 6 Tahun 2014 tentang Desa. ${ }^{7}$

Berdasarkan penjabaran tersebut diatas dapat dijelaskan bahwa Negara Kesatuan Republik Indonesia sudah melindungi keberadaan desa sejak era awal kemerdekaan yaitu tepatnya pada tahun 1948 dengan adanya Undang-undang Nomor 22 Tahun 1948 tentang Pokok Pemerintahan Daerah. Tetapi UndangUndang tersebut saat ini sudah tidak berlaku lagi, digantikan dengan peraturan perundang-undangan yang baru dan sudah sesuai dengan perkembangan zaman saat

\footnotetext{
${ }^{7}$ Anonim, Riwayat Perundang-undangan Desa, http://format-lengkap-administrasidesa.blogspot.co.id/2016/08/riwayat-perundangundangan-desa-dari.html, diakses tanggal 4 april 2018
} 
ini yaitu Undang-undang Nomor 6 Tahun 2014 tentang Desa.

Terdapat pula asas pengaturan desa dalam Undang-Undang antara lain:

1) Rekognisi, yaitu pengakuan terhadap hak asal usul.

2) Subsidiaritas, yaitu penetapan kewenangan berskala lokal dan pengambilan keputusan secara lokal untuk kepentingan masyarakat Desa.

3) Keberagaman, yaitu pengakuan dan penghormatan terhadap sistem nilai yang berlaku di masyarakat Desa, tetapi dengan tetap mengindahkan sistem nilai bersama dalam kehidupan berbangsa dan bernegara.

4) Kebersamaan, yaitu semangat untuk berperan aktif dan bekerja sama dengan prinsip saling menghargai antara kelembagaan di tingkat Desa dan unsur masyarakat Desa dalam membangun Desa.

5) Kegotongroyongan, yaitu kebiasaan saling tolong-menolong untuk membangun Desa.

6) Kekeluargaan, yaitu kebiasaan warga masyarakat Desa sebagai bagian dari satu kesatuan keluarga besar masyarakat Desa.

7) Musyawarah, yaitu proses pengambilan keputusan yang menyangkut kepentingan masyarakat Desa melalui diskusi dengan berbagai pihak yang berkepentingan.

8) Demokrasi, yaitu sistem pengorganisasian masyarakat Desa dalam suatu sistem pemerintahan yang dilakukan oleh masyarakat Desa atau dengan persetujuan masyarakat Desa serta keluhuran harkat dan martabat manusia sebagai makhluk Tuhan Yang Maha Esa.

9) Kemandirian, yaitu suatu proses yang dilakukan oleh Pemerintah Desa dan masyarakat Desa untuk melakukan suatu kegiatan dalam rangka memenuhi kebutuhannya dengan kemampuan sendiri.

10) Partisipasi, yaitu turut berperan aktif dalam suatu kegiatan.

11) Kesetaraan, yaitu kesamaan dalam kedudukan dan peran.

12) Pemberdayaan, yaitu upaya meningkatkan taraf hidup dan kesejahteraan masyarakat Desa melalui penetapan kebijakan, program, dan kegiatan yang sesuai dengan esensi masalah dan prioritas kebutuhan masyarakat Desa.

13) Keberlanjutan, yaitu suatu proses yang dilakukan secara terkoordinasi, terintegrasi, dan berkesinambungan dalam merencanakan dan melaksanakan program pembangunan Desa. ${ }^{8}$

Sedangkan tujuan pengaturan desa dalam Undang-Undang antara lain:

1) memberikan pengakuan dan penghormatan atas Desa yang sudah ada dengan keberagamannya sebelum dan sesudah terbentuknya Negara Kesatuan Republik Indonesia.

2) memberikan kejelasan status dan kepastian hukum atas Desa dalam sistem ketatanegaraan Republik Indonesia demi mewujudkan

\footnotetext{
${ }^{8}$ Undang-undang Nomor 6 Tahun 2014 tentang Desa
} 
keadilan bagi seluruh rakyat Indonesia.

3) melestarikan dan memajukan adat, tradisi, dan budaya masyarakat Desa.

4) mendorong prakarsa, gerakan, dan partisipasi masyarakat Desa untuk pengembangan potensi dan Aset Desa guna kesejahteraan bersama.

5) membentuk Pemerintahan Desa yang profesional, efisien dan efektif, terbuka, serta bertanggung jawab.

6) meningkatkan pelayanan publik bagi warga masyarakat Desa guna mempercepat perwujudan kesejahteraan umum.

7) meningkatkan ketahanan sosial budaya masyarakat Desa guna mewujudkan masyarakat Desa yang mampu memelihara kesatuan sosial sebagai bagian dari ketahanan nasional.

8) memajukan perekonomian masyarakat Desa serta mengatasi kesenjangan pembangunan nasional.

9) memperkuat masyarakat Desa sebagai subjek pembangunan. ${ }^{9}$

\section{Kesimpulan}

Perlindungan hukum terhadap desa di Indonesia, berdasarkan sejarah upaya perlindungan hukum terhadap keberadaan desa sudah dilakukan sejak era awal kemerdekaan yaitu tepatnya pada tahun 1948 dengan adanya Undang-undang Nomor 22 Tahun 1948 tentang Pokok Pemerintahan Daerah. Tetapi UndangUndang tersebut saat ini sudah tidak berlaku lagi, digantikan dengan peraturan perundang-undangan yang baru dan sudah sesuai dengan perkembangan zaman saat ini yaitu Undang-undang Nomor 6 Tahun 2014 tentang Desa.

\section{Daftar Pustaka}

Anonim, 20 Pengertian Desa Menurut Para Ahli Terlengkap, http://www.pelajaran.co.id/2017/17/ 20 pengertian -desa- menurut- paraahli- terlengkap.html, diakses tanggal 19 April 2018

Anonim, Pengertian Negara Hukum Menurut Para Ahli, https: //tesishukum.com/pengertian-negarahukum-menurut-para-ahli/, diakses tanggal 19 april 2018

Anonim, Riwayat Perundang-undangan Desa, http://format-lengkapadministrasi-

desa.blogspot.co.id/2016/08/riwayatperundang-undangan-desa-dari.html, diakses tanggal 4 april 2018

Rahardjo, Satjipto, 2008. Membedah Hukum Progresif. Jakarta: Penerbit Buku Kompas.

Ryan Febrianti, Memahami Metode Penelitian Kepustakaan, http://ryanfebrianti.blogspot.co.id/2015/03/me mahami-metode-penelitiankepustakaan.html?m=1 diakses tanggal 19 april 2018.

Sugiyono. 2009. Metode Penelitian Kuantitatif Kualitatif dan $R \& D$. Bandung: Penerbit Alfabeta.

Soekanto, Soerjono, 1983. Penegakan Hukum. Jakarta: Penerbit Bina Cipta. Undang-undang Nomor 6 Tahun 2014 Tentang Desa

\footnotetext{
${ }^{9}$ Ibid
} 